\title{
International Journal of Ayurveda and Pharma Research
}

\author{
Review Article
}

GUDA VARTI FOR POST-OPERATIVE PAIN MANAGEMENT- ROAD LESS TRAVELLED

\section{Vilas Thakre Kalpita1*, P Bhat Ramesh ${ }^{2}$}

${ }^{*}$ P.G. Scholar, ${ }^{2}$ H.O.D and Principal, Department of Shalya Tantra, Sri Sri College of Ayurvedic Science and Research Hospital, Bengaluru, Karnataka, India.

\begin{abstract}
Acute pain is an unpleasant sensory, emotional and mental sensation (experience) associated with vegetative signs, psychological response and changes in behavior. Postoperative pain is one such example and adequate management becomes utmost necessary. In Shalya tantra practice, proctology is the field of excellence for many practitioners and post-operative pain is an acquaintance difficult to handle. Many practitioners still resort to using contemporary I.M OR I.V analgesics for pain management which have proven ADR'S due to lack of availability of Ayurvedic analgesics for management. Vartis (suppositories) was in vogue since pre-historic times and have been mentioned in almost all Ayurvedic texts for various disorders with suitable formulations and various modes of insertion, e.g.: Ratadi varti for Shoola. Ayurveda also has a wide-range of drugs mentioned for relieving pain which have not been used to the full potential. Hence Guda varti as a drug delivery system for pain management needs to be explored in Ayurveda Shalya tantra practice.
\end{abstract}

KEYWORDS: Guda varti, Suppository, Post-operative pain.

\section{INTRODUCTION}

The goal for post-operative pain management is to reduce or eliminate pain and discomfort with minimum side effects ${ }^{[1]}$. According to the 'American society of anesthesiologist practice guidelines for acute pain management in peri-operative setting', acute pain is defined as pain present in surgical patient because of pre-existing disease, the surgical procedure or a combination of disease related and procedure related sources. ${ }^{2]}$

The effective management of such pain becomes a hurdle for many Ayurvedic practitioners. In the field of Shalya tantra as proctology being the main field of excellence, the lack of available potent analgesics to relieve pain locally after surgery results in practitioners using contemporary I.M or I.V analgesics or diclofenac suppositories which have been proven to be highly Nephrotoxic ${ }^{[3]}$ and hepatotoxic ${ }^{[4]}$. Vartis which have been in vogue since the pre-historic times needs to be explored as a better alternative to provide analgesia in Ayurveda.

\section{Vartis and Suppositories}

Nirukti-Vartayateeti Vartihi[5]

Definition- Vartiriva svarupatvata Vartih namna prakrititah. ${ }^{6]}$

Medicines are powdered, triturated and given the Varti shape i.e., like the wick of a lamp and that is why it is called as Varti Kalpana. Varti resembles Vati in all respects like preparation etc, but differs in shape and mode of administration. Eg: Guda vartimedicines are made into Yavakriti[7].

Varti Kalpana has been mentioned in various texts like Sharangdhara, (14th AD) Yogaratnakara $\left(16^{\text {th }}\right.$ AD) Bhavaprakash (16 th $\left.A D\right)$ Bhaishajya ratnavali $\left(20^{\text {th }} \mathrm{AD}\right)$ and many more.

Vartis are used for local administration through the following routes viz. Guda (Anus), Yoni (Vagina), Sishna (Penis), and Netra (Eye) and based on the route of drug administration, the length and diameter of the Varti will be modified.

\section{Types of Vartis ${ }^{[8]}$}

1) Depending on size: Guda varti (Angushtha pramana) (Pusphanetrvat), Dhumavarti (Yavakara) etc.

2) Depending upon the indication at particular site: Guda Varti, Yoni Varti, Vrana Varti, Sishna Varti, Dhuma Varti, Netra Varti.

3) Depending on composition: Phala vartimadanaphala as main ingredient

4) Depending upon the action: Soumya-for Snehana poshana and Roopana karma and Teekshana for Virechana and Lekhana karma. 


\section{Guda varti (rectal suppositories)}

Are inserted in the anal route and hence called Guda Vartis. They aid in Vata (Apana vayu) Anulomana and expulsion of Mala. They are indicated in Udavarta, Adhmana and Shola.

When used, the Varti is first soaked in Ghrita and then is inserted in the rectum slowly.

Eg: Phala Varti

\section{General method of preparation [8]}

Usually, two methods are employed here,

Paka method: Jaggery/sugar along with water boiled together over a mild fire until Paka of 2 to 3 thread consistency. Later the fine powder of medicinal drugs is added little by little and stirred well to attain a homogenous mixture and desired sized Varti are prepared.

Bhavana method: Fine powder of the medicinal drugs is mixed together and triturated along with the liquid media mentioned in the preparation. Later desired sized Varti are prepared.

\section{Suppositories}

The term suppositories have its origin in Latin and means, "to place under". Suppositories are a medicated solid dosage form intended for insertion into the body orifices. Suppositories and creams are the two main modes of administration of drugs through the rectum. They are used to deliver both systemically acting and locally-acting medications. The general principle is that the suppositories is inserted as a solid, and dissolve or melt inside the body to deliver the medicine pseudo received by the many blood vessels that follow the larger intestine. The suppository was first used in nursing facilities to be administered elderly patients who were not capable of taking medications. Suppositories come in various sizes and shapes which facilitate their insertion and retention in the cavity. Adult rectal suppositories weighed about $2 \mathrm{gm}$ while those for children are about half that weight. [9]

\section{Method of preparation [9]}

1. Hand rolling: It is the oldest and simplest method of suppository preparation and may be used when only a few suppositories are to be prepared in a cocoa butter base. A plastic-like mass is prepared by triturating grated cocoa butter and active ingredients in a mortar. The mass is formed into a ball in the palm of the hands, and then rolled into a uniform cylinder. The cylinder is then cut into the appropriate number of pieces which are rolled on one end to produce a conical shape.

2. Compression Molding: It is a method of preparing suppositories from a mixture of grated suppository base and medicaments which is forced into a special compression mold.

3. Fusion Molding: It involves first melting the suppository base and then dispersing or dissolving the drug in the melted base. The mixture is removed from the heat and poured into a suppository mold. When the mixture has congealed the suppositories are removed from the mold. Since the components are measured by weight but compounded by volume density calculations and mold calibrations are required to provide accurate doses.

\section{Physiology of rectal absorption}

The veins of the rectum comprise the superior hemorrhoidal vein, which drains into the inferior mesenteric and portal system, and the middle and inferior hemorrhoidal veins, which enter the systemic venous circulation via the internal iliac veins. However, the inferior and middle hemorrhoidal veins bypass the liver and do not undergo first pass metabolism. Therefore, the drugs delivered through suppositories to the lower and middle hemorrhoidal veins are absorbed rapidly and effectively. The rectum is an interesting area for drug absorption because it is not buffered and has a neutral $\mathrm{pH}$. It also has a very little enzymatic activity; thus, enzymatic degradation does not occur. The rectal mucus is more capable of tolerating various drug related irritations than the gastric mucosa..10]

\section{Factors affecting the absorption}

- Rectal gut-wall metabolism and metabolism by micro-organisms in the rectal lumen may decrease bioavailability.[11]

- Biochemical composition of the drug inserted.

\section{Advantages of Rectal Route Administration [11]}

- No issues with oral abidance thus avoiding nausea and vomiting- Easily administered in unconscious patients.

- The achievement of a rapid systemic effect by giving a drug in a suitable solution (as an alternative to parental administration).

- Drug absorption may be easily discontinued in the event of an accidental overdose.

- The rate of drug absorption is not influenced by ingestion of food or the rate of gastric emptying

- First-pass elimination of high clearance drugs may be partly avoided.

- Contact with digestive fluids of the upper gastrointestinal tract is avoided, thereby preventing breakdown of some drugs.

Disadvantages of Rectal Route Administration [11]

- Interruption of absorption by defecation, which may occur particularly with irritant drugs. 
- The surface area of the rectum is far smaller for absorption than that of the duodenum.

- The fluid contents of the rectum are much smaller than those of the duodenum and this may produce problems with dissolution of some drugs -patient acceptability may be a problem.

\section{DISCUSSION}

- Concept of Vartis has been widely discussed in the Ayurvedic treatises of Charaka Samhita, Sushruta Samhita, Bhaishajya Kalpana, Sharangdhara and many more which helps us understand the importance and efficacy of rectal route of administration of drugs.

- Bhaishajya ratnavali widely contributes different Guda Vartis in different diseases like Udavarta, Atisara and Arshas. Chakradatta also explains in detail about Guda Vartis for the treatment of Shula, Arshas and Udavarta showing the diversity of diseases in which it was being utilized.

- Acharayas also give a detailed method of preparation and sizing of the Vartis for different routes of administration according to the disease intended to cure. Eg: Pippalyadi guda varti- used in Udara vikara, Adhmana.

- Contemporary science too has mentioned the importance of suppositories and developed formulations in close synchronization with the Varti Kalpana.

- The contemporary science works on postoperative pain by administration of analgesics and NSAIDS which is proven to be harmful and have varied recorded ADR'S.

- Ayurveda is the repository of drugs which are known to cure almost every illness and more, even so mentions different formulations of the same drugs to suit the patient without harming the efficacy of the drugs.

- Extensive research and study are further required to enhance the understanding about management of pain through Varti in Ayurveda.

\section{CONCLUSION}

Today, as there is increasing use of traditional medicine in proctology, there is a growing need to eliminate the myths about Ayurveda medicines not being efficient enough to curb post-operative pain. Guda Varti helps in Apana Vayu Anulomana, thereby helping reduce the pain as Vata is considered as the main culprit for inducing pain.

Varti administration represents a convenient, alternative route of drug administration. They are in an acceptable form, safe and easier for administration with a higher rate of bioavailability, and less wastage, can target delivery system with a lower dose and reduce systemic toxicity.
Keeping in mind all the factors aiding in the bio-availability of the drug efficacy and ease of administration more formulations can be converted into Varti to achieve the desired therapeutic effects.

\section{REFERENCES}

1. Garimella V, Cellini C. Postoperative Pain Control. Clinics in Colon and Rectal Surgery [Internet]. 2013b Aug 19 [cited 2019 Feb 18]; 26(03): 1916. Available from: https://www.ncbi.nlm.nih.gov/ pmc/articles/PMC3747287

2. Practice Guidelines for Acute Pain Management in the Peri-operative Setting An Updated Report by the American Society of Anesthesiologists Task Force on Acute Pain Management. Anesthesiology: The Journal of the American Society of Anesthesiologists [Internet]. 2004 Jan 1 [cited 2019 Feb 18]; 100(6):1573-81. Available from:

http://anesthesiology.pubs.asahq.org/article.asp $\mathrm{x}$ ?articleid $=1943172$

3. Hickey EJ, Raje RR, Reid VE, Gross SM, Ray SD. Diclofenac induced in vivo nephrotoxicity may involve oxidative stress-mediated massive genomic DNA fragmentation and apoptotic cell death. Free radical biology \& medicine [Internet]. 2001 [cited 2019 Feb 18]; 31(2): 139-52. Available from: https://www.ncbi.nlm.nih.gov/pubmed/114408 26

4. Diclofenac [Internet]. Nih. gov. 2017 b [cited 2019 Feb 18]. Available from: https://livertox.nih.gov/Diclofenac.html

5. Joshi Sunil Kumar. Shashti Upakarama.1 $1^{\text {st }}$ edi. Delhi: Chaukhamba samskrita pratishtana; 2005. Chapter 28. Pp no.226.

6. Sushruta. Sushruta Samhita, with commentaries Nibandha sangraha of Dalhana and Nyaya chandrika of Gayadasa, edited by Acharya YT. 8thed. Varanasi: Chakambha Orientalia; 2005. Chikitsa stana. Chapter 1. Verse no 15.

7. Angadi Ravindra. A textbook of Bhaishya Kalpana vigyana. 2ndreviseded.Varanasi: Chaukhamba publication; 2016.Pp.232.

8. Angadi Ravindra. A textbook of Bhaishya Kalpana vigyana. 2ndreviseded. Varanasi: Chaukhamba publication; 2016.Pp.233

9. Baviskar P, Bedse A, Sadique S, Kunde V, Jaiswal. Drug Delivery on Rectal Absorption: Suppositories. Int. J. Pharm. Sci. Rev. Res., 21(1), Jul - Aug 2013; 13, 70-76. Available from: http://globalresearchonline.net/journalcontents /v21-1/13.pdf

10. Gupta PJ. Suppositories in anal disorders: a review. European review for medical and 
pharmacological sciences [Internet]. 2007 [cited 2020 Apr 13]; 11(3):165-70. Available from: https://www.ncbi.nlm.nih.gov/pubmed/179702 32

11. De Boer Ag, De Leede Lgj, Breimer Dd. Drug Absorption By Sublingual And Rectal Routes.

\section{Cite this article as:}

Vilas Thakre Kalpita, P Bhat Ramesh. Guda Varti for Post-Operative Pain Management- Road Less Travelled. International Journal of Ayurveda and Pharma Research. 2021;9(1):90-93.

Source of support: Nil, Conflict of interest: None Declared
British Journal of Anaesthesia [Internet]. 1984 Jan; 56(1): 69-82. Available from: https:// bjanaesthesia.org/article/S0007-0912(17)42397 $-\mathrm{X} / \mathrm{pdf}$.
*Address for correspondence Dr. Vilas Thakre Kalpita PG Scholar,

Department of Shalya Tantra, Sri Sri College of Ayurvedic Science And Research Hospital, Bengaluru, Karnataka, India.

Email: kalpitathakre@gmail.com

Disclaimer: IJAPR is solely owned by Mahadev Publications - dedicated to publish quality research, while every effort has been taken to verify the accuracy of the content published in our Journal. IJAPR cannot accept any responsibility or liability for the articles content which are published. The views expressed in articles by our contributing authors are not necessarily those of IJAPR editor or editorial board members. 